GLASILO

FUTURE

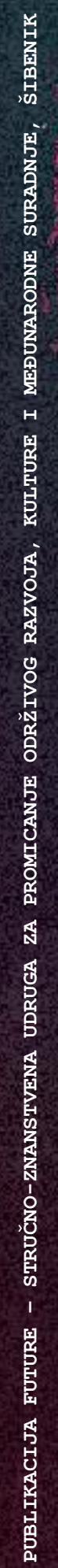

VOLUMEN 1 BROJ 5-6

PROSINAC 2018.

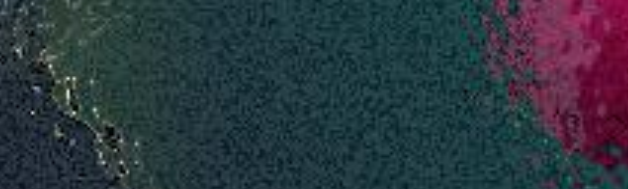

UDK 60

UDK 631

UDK 630

UDK 336

UDK 338
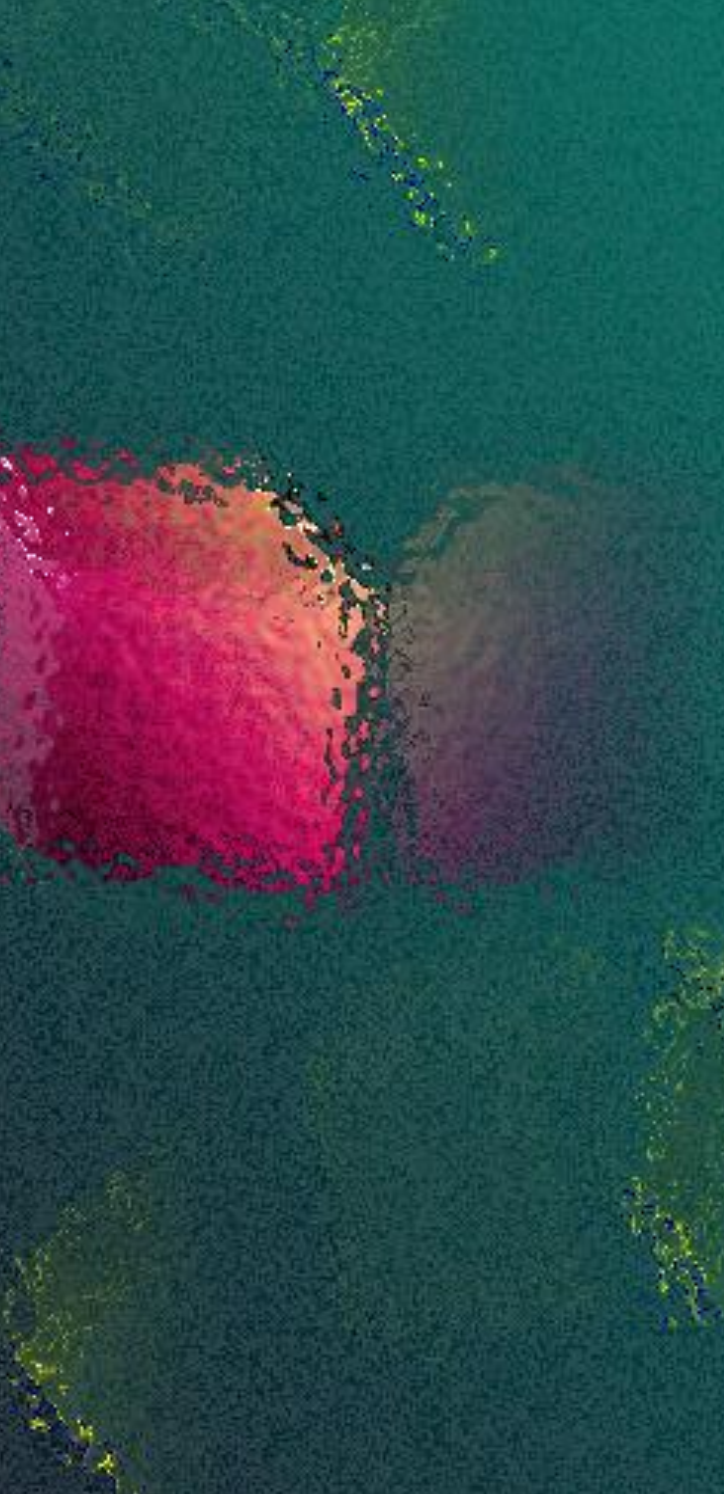


\section{Glasilo Future}

\section{Stručno-znanstveni časopis}

Nakladnik: FUTURA

\section{FUTUR}

Sjedište udruge: Šibenik

\section{Adresa uredništva:}

Bana Josipa Jelačića 13 a, 22000 Šibenik, Hrvatska / Croatia 留 / 圆: +385 (0) 022218133

$\triangle$ : urednistvo@gazette-future.eu / editors@gazette-future.eu (3): www.gazette-future.eu

\section{Uređivački odbor / Editorial Board:}

Doc. dr. sc. Boris Dorbić, v. pred. - glavni i odgovorni urednik / Editor-in-Chief

Emilija Friganović, dipl. ing. preh. teh., v. pred. - zamjenica g. i o. urednika / Deputy Editor-in-Chief

Ančica Sečan Matijaščić, mag. act. soc. - tehnička urednica / Technical Editor

Antonia Dorbić, mag. art. - zamjenica tehničke urednice / Deputy Technical Editor

Prof. dr. sc. Željko Španjol

Mr. sc. Milivoj Blažević

Vesna Štibrić, dipl. ing. preh. teh.

\section{Međunarodno uredništvo / International Editorial Board:}

Prof. dr. sc. Kiril Bahcevandziev - Portugal (Instituto Politécnico de Coimbra)

Prof. dr. sc. Martin Bobinac - Srbija (Šumarski fakultet Beograd)

Doc. dr. sc. Zvezda Bogevska - Makedonija (Fakultet za zemjodelski nauki i hrana Skopje)

Dario Bognolo, mag. ing. - Hrvatska (Veleučilište u Rijeci)

Prof. dr. sc. Agata Cieszewska - Poljska (Szkoła Główna Gospodarstwa Wiejskiego w Warszawie)

Dr. sc. Bogdan Cvjetković, prof. emeritus - Hrvatska (Agronomski fakultet Zagreb)

Prof. dr. sc. Duška Ćurić - Hrvatska (Prehrambeno-biotehnološki fakultet Zagreb)

Doc. dr. sc. Margarita Davitkovska - Makedonija (Fakultet za zemjodelski nauki i hrana Skopje)

Doc. dr. sc. Dubravka Dujmović Purgar - Hrvatska (Agronomski fakultet Zagreb)

Prof. dr. sc. Semina Hadžiabulić - Bosna i Hercegovina (Agromediteranski fakultet Mostar)

Prof. dr. sc. Péter Honfi - Mađarska (Faculty of Horticultural Science Budapest)

Prof. dr. sc. Valeria Ivanova - Bugarska (Fakultet za lozaro-gradinarstvo Plovdiv)

Doc. dr. sc. Orhan Jašić - Bosna i Hercegovina (Filozofski fakultet Tuzla)

Prof. dr. sc. Tajana Krička - Hrvatska (Agronomski fakultet Zagreb)

Prof. dr. sc. Biljana Lazović - Crna Gora (Biotehnički fakultet Podgorica)

Prof. dr. sc. Bosiljka Mustać - Hrvatska (Sveučilište u Zadru)

Hrv. akademik prof. dr. sc. Stanislav Nakić - Bosna i Hercegovina (Sveučilište Hercegovina Mostar)

Sandra Popović, mag. ing. - Srbija (Poljoprivredni fakultet Beograd)

Doc. dr. sc. Bojan Simovski - Makedonija (Šumarski fakultet Skopje)

Prof. dr. sc. Davor Skejić - Hrvatska (Građevinski fakultet Zagreb)

Doc. dr. sc. Milan Stanković - Srbija (Univerzitet u Kragujevcu)

Akademik prof. dr. sc. Refik Šećibović - Bosna i Hercegovina (Visoka škola za turizam i menadžment Konjic)

Prof. dr. sc. Andrej Šušek - Slovenija (Fakulteta za kmetijstvo in biosistemske vede Maribor)

Prof. dr. sc. Elma Temim - Bosna i Hercegovina (Agromediteranski fakultet Mostar)

Doc. dr. sc. Ivana Vitasović Kosić - Hrvatska (Agronomski fakultet Zagreb)

Doc. dr. sc. Ana Vujošević - Srbija (Poljoprivredni fakultet Beograd)

Prof. dr. sc. Vesna Židovec - Hrvatska (Agronomski fakultet Zagreb)

Lektura i grafička priprema: Ančica Sečan Matijaščić, mag. act. soc.

Objavljeno: 31. prosinca 2018. godine.

Časopis izlazi u elektroničkom izdanju dva puta godišnje, krajem lipnja i prosinca, a predviđena su i dva interdisciplinarna specijalna izdanja tijekom godine iz STEM i ostalih znanstvenih/umjetničkih područja.

Časopis je besplatan. Rukopisi i recenzije se ne vraćaju i ne honoriraju.

Umnožavanje (reproduciranje), stavljanje u promet (distribuiranje), priopćavanje javnosti, stavljanje na raspolaganje javnosti odnosno prerada u bilo kojem obliku nije dopuštena bez pismenog dopuštenja Nakladnika. Sadržaj objavljen u Glasilu Future može se slobodno koristiti u osobne i obrazovne svrhe uz obvezno navođenje izvora. 


\section{Glasilo Future}

\section{Stručno-znanstveni časopis}

FUTURA - stručno-znanstvena udruga za promicanje održivog razvoja, kulture i međunarodne suradnje, Bana Josipa Jelačića 13 a, 22000 Šibenik, Hrvatska

(2018) $1(5-6) 01-52$

\section{SADRŽAJ:}

\section{Izvorni znanstveni rad (original scientific paper)}

Str.

B. Dorbić, Lea Zemunović, Tea Zemunović, Emilija Friganović, Elma Temim, Katica Arar

Istraživanje općih saznanja o nekim vrstama trajnica na Mediteranu

A research on common knowledge about some perennial species in the Mediterranean region

Branka Stipanović

Stavovi maslinara o podizanju konkurentnosti maslinarstva u Dalmaciji u kontekstu ARISTOIL projekta

Attitudes of olive growers in Dalmatia region about competiveness growth in context of ARISTOIL project

\section{Stručni rad (professional paper)}

\section{Blažević}

Ogled o urbanim i prirodnim vrijednosnicama Šibenika u kontekstu turističke perspektive

An overview of urban and natural values of Šibenik in the context and from tourism perspective

J. E. Meeker, Z. Lišnić, B. Dorbić, Emilija Friganović, Ž. Španjol, Zvezda Bogevska Mogućnosti uporabe nekih jestivih submediteranskih autohtonih i alohtonih vrsta za održive dekorativne vrtove na kršu

Opportunities for use of some edible sub-Mediterranean autochthonous and allochthonous species for sustainable ornamental gardens in karst landscapes

\section{Nekategorizirani rad (uncategorised paper)}

\section{Zdenka Bilušić}

Vijesti

News 


\title{
Ogled o urbanim i prirodnim vrijednosnicama Šibenika u kontekstu turističke perspektive
}

\section{An overview of urban and natural values of Šibenik in the context and from tourism perspective}

\author{
Milivoj Blažević ${ }^{1 *}$
}

stručni rad (professional paper)

doi: 10.32779/gf.1.5-6.3

\section{Sažetak}

Povijesne gradske jezgre na našoj obali danas su postale pozornica mnogobrojnim turistima. Uz pozitivne aspekte navedenog, kroz zapošljavanje lokalnog stanovništva i jačanje gospodarstva, pojavile su se i negativne posljedice. Sve se pokušava uskladiti turističkoj ponudi, što utječe na sezonski karakter života u gradskoj jezgri. Ovim radom se kroz sažeti prikaz urbanističkih, kulturnih i prirodnih vrijednosti želi usmjeriti budućnost u uprizorenje i novi život zaboravljenih šibenskih vrijednosti u cilju turističke valorizacije. Bogata šibenska baština jednostavno od nas traži da se u suvremenosti izvuče iz naslaga zaborava kao moderna brendirana slika u razvoju turizma. Šibenik posjeduje veliku cjelinu starog grada, crkve, muzeji, biblioteke, tvrđave, nautičke luke itd. koje uz mjesnu gastronomiju i sport čine glavni temelj turizma. Stoga je i komunalno i krajobrazno uređenje grada prioritet u cilju toga postignuća. Također se kao naš značajni adut moraju izdvojiti i prirodne vrijednosti (razvedenost šibenskog zaljeva, areal Gornjeg i Donjeg polja, rijeka Krka itd.). Šibenik je mjesto rođenja i djelovanja čitavog niza humanista, književnika, umjetnika i prirodoslovaca. Ove godine se bilježi i 140-ta godišnjica od smrti šibenskog i svjetskog botaničara R. Visianija.

Ključne riječi: urbanizam, povijest, prirodoslovlje, vrijednosnice, brendiranje, Šibenik.

\begin{abstract}
Historical urban nuclei along the Croatian coastline are currently intended as a stage for a large number of tourists. In addition to positive aspects of what has previously been mentioned through employment of local population and strengthening of the economy, we have also witnessed negative consequences. Everything is striving to be harmonized with tourism programs, which affects the seasonal character of life in the urban nucleus. Through a brief overview of urban, cultural and natural values, this paper is striving to steer the future towards a new life and the revival of the forgotten
\end{abstract}

\footnotetext{
${ }^{1}$ Mr. sc. Milivoj Blažević, prof., 8. dalmatinske udarne brigade 20, 22000 Šibenik, Republika Hrvatska.

* E-mail: milivoj.blazevic@ gmail.com.
} 
values of Šibenik for the purpose of tourism valorization. The rich local heritage simply currently requires to be taken out from the layers of oblivion as a modern branded image in tourism development. Šibenik possesses a huge entity of the old town, churches, museums, libraries, fortresses and nautical ports, among others, which, in addition to local gastronomy and sports, provide the foundations of tourism. Consequently, municipal land use development and landscape gardening in the city is a priority while striving to meet these objectives. Moreover, it is important to highlight the natural values (the indentation of the Bay of Šibenik, the areas covered by Donje and Gornje Polje and the Krka River, to name a few) as an ace up our sleeve. Šibenik is the place of birth of a large number of humanists, artists and natural scientists who have also operated in this area. This year we will be marking the $140^{\text {th }}$ anniversary of the death of the Šibenik and international botanist R. Visiani.

Key words: urbanism, history, natural sciences, security, branding, Šibenik.

\section{Uvod}

Društveni interes za zaštitu i očuvanje povijesnih gradskih središta i početkom 21. stoljeća pokazuje svoju vitalnost te se pristupi revitalizaciji kreću u različitim rasponima očuvanja i zaštite pojedinačnih reprezentativnih objekata ili cijelih povijesnih gradskih jezgara. Revitalizacijski modeli mogu se sagledati u rasponu od izgradnje novog i poništavanju već izgrađenog (Maroević, 1986, prema Poljičak, 2014). Demografsko propadanje jedan je od najvažnijih socioloških aspekata stanja u povijesnim gradskim jezgrama u Hrvatskoj (Poljičak, 2014).

Kulturno nasljeđe se oblikuje kao proizvod i nudi na tržištu, te postaje primarni i sekundarni motiv putovanja sve šireg segmenta rastućeg tržišta kulturnog turizma. Stvaranje i razvoj turističkog proizvoda u kulturnom turizmu temelji se na razvoju menadžmenta kulturnih resursa i primjeni marketinške koncepcije koja polazi od zadovoljstva korisnika, a u kulturnom se turizmu zadovoljstvo postiže očuvanjem kvalitete resursa na kojem se temelji turistička ponuda (Pančić Kombol, 2006).

Posljednjih godina, povijesne gradske jezgre na našoj obali postale su pozornica mnogobrojnim turistima. Uz pozitivne aspekte navedenog (mogućnost zapošljavanja lokalnog stanovništva, jačanje uloge turističkog gospodarstva) pojavile su se i negativne posljedice. Sve se pokušava prilagoditi turističkoj ponudi, što utječe na sezonski karakter života u gradskoj jezgri (Poljičak, 2014).

Problematika teme upućuje na potrebu da se vrijednosnice lokalnoga nasljeđa i bogate kulturne tradicije pokušavaju na suvremeni način prezentirati u recentnoj turističkoj djelatnosti. Stoga je ovaj rad prilog kojim se kroz sažeti prikaz urbanističkih, kulturnih i prirodnih vrijednosti želi usmjeriti budućnost u uprizorenje i novi život zaboravljenih šibenskih vrijednosti. Valorizacija lokalnih vrijednosti će doprinijeti novoj preglednosti i usmjerenju turizma kao brenda modernog vremena. 


\section{Razne mogućnosti u turističkom razvoju grada Šibenika}

U ozračju novoga doba do danas, i promet, i baština, i otvorenost postali su interes u prihvatu recentne turističke slike grada koji traje. Treba istaknuti da će ovakav suvremeni turističko-medijalni i svekoliki gospodarski napredak temeljen na lokalnoj tradiciji i vrijednoj baštini razdoblja proteklog vremena iznjedriti novu i prikladniju praksu. Na toj točki se prepoznaje mogućnost uporabe školovane i intelektualno educirane generacije koja će prirodnim elementima turističko-krajobrazne kulture dati određeni oblik šarolikog modernizma. To je baština zelenog grada, zelenog otoka i cvjetne geometrije u modernom gradskom tkivu koja će stvarati ugođaj nove sinergije (Slike 1. i 2.).

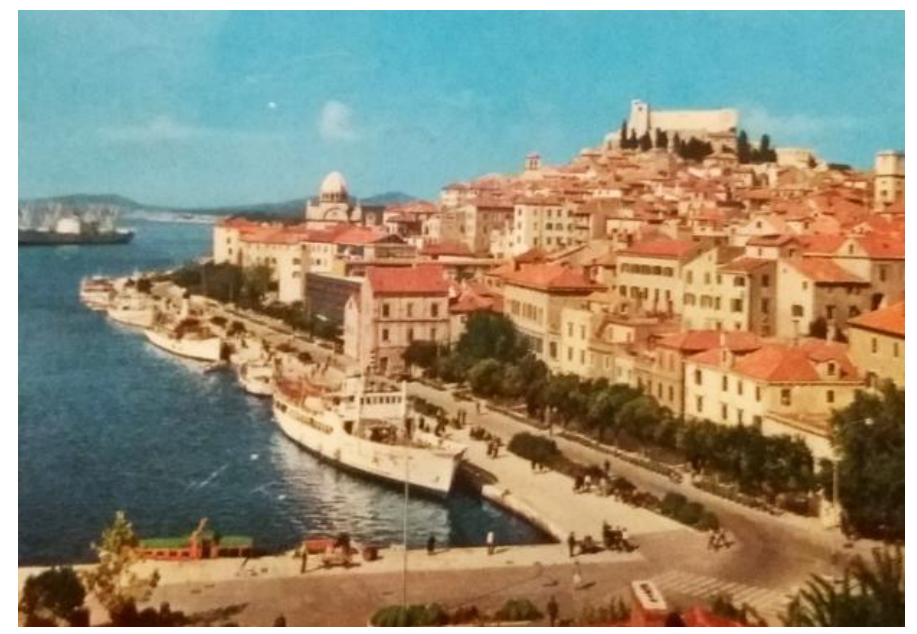

Slika 1. Šibenska obala 1969. godine (Blažević, 200-).

Figure 1. Šibenik coast in 1969. (Blažević, 200-).

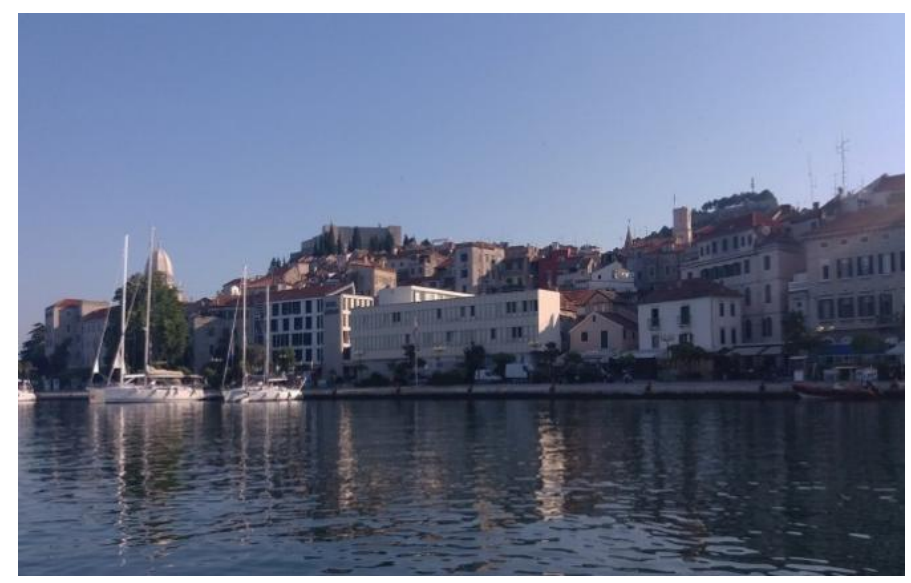

Slika 2. Šibenska obala 2018. godine (Foto: B. Dorbić).

Figure 2. Šibenik coast in 2018. (Photo: B. Dorbić).

Interes za umjetničko poimanje turizma kao prizme životnog susreta i ljudske komunikacije, kako na osobnom tako i na internacionalnom planu, biti će uputnica održivog razvoja grupe, mjesta i regije te će najbolje iz te djelatnosti uzimati kao iskustvenu odrednicu raznolikog turističkog potencijala. Programom E-20 i sustavom digitalizacije te širokom informacijom postići će se rezultati veće razine 
marketinških aktivnosti i kampanja, što ima velikog značaja u novom formatu rastućeg kulturnog turizma i njegovog brendiranja.

Cjelina starog grada, crkve, muzeji, biblioteke, tvrđave, vidikovci, kavane, nautičke luke itd. postaju uz mjesnu gastronomiju i sport glavni temelji turizma koji uključivanjem u javni prostor dobiva nove polete. Elementi ruralnog nasljeđa, folklora, pjesme i trivijalne tradicije vidno doprinose toj općoj slici.

Likovni performans - tehnološko aktivni ugradbeni video ekrani u gradskom središtu s priključkom na bazu u cjelini mogu postati reklamna oglasnica brenda kao značajne tradicije video-filmskog zapisa, mjesta i podneblja u promociji njegove baštine. To je novo lice povratka izgubljenog vremena o čijoj spoznaji strani gosti i domicilno građanstvo postaju svakodnevni konzumenti.

Posebno sada, i u budućnosti, potrošači iz dalekih istočnih i egzotičnih destinacija šibensku kulturu poimaju kao otkriće. Na taj način se na tradiciji kulturno-krajobrazne baštine i gastronomskog nasljeđa izvodi novo vrednovanje nacionalnih spoznaja o kojima dugo vremena ili nismo svjedočili ili su ostali u zaboravu. Šibenik u tom pogledu ima velike mogućnosti, naročito stoga jer njegova kulturna i trivijalna povjesnica osuvremenjena modernističkim aplikacijama može generirati značajne rezultate. Stoga je i komunalno uređenje grada prioritet u cilju toga postignuća (Slike 3. i 4.).

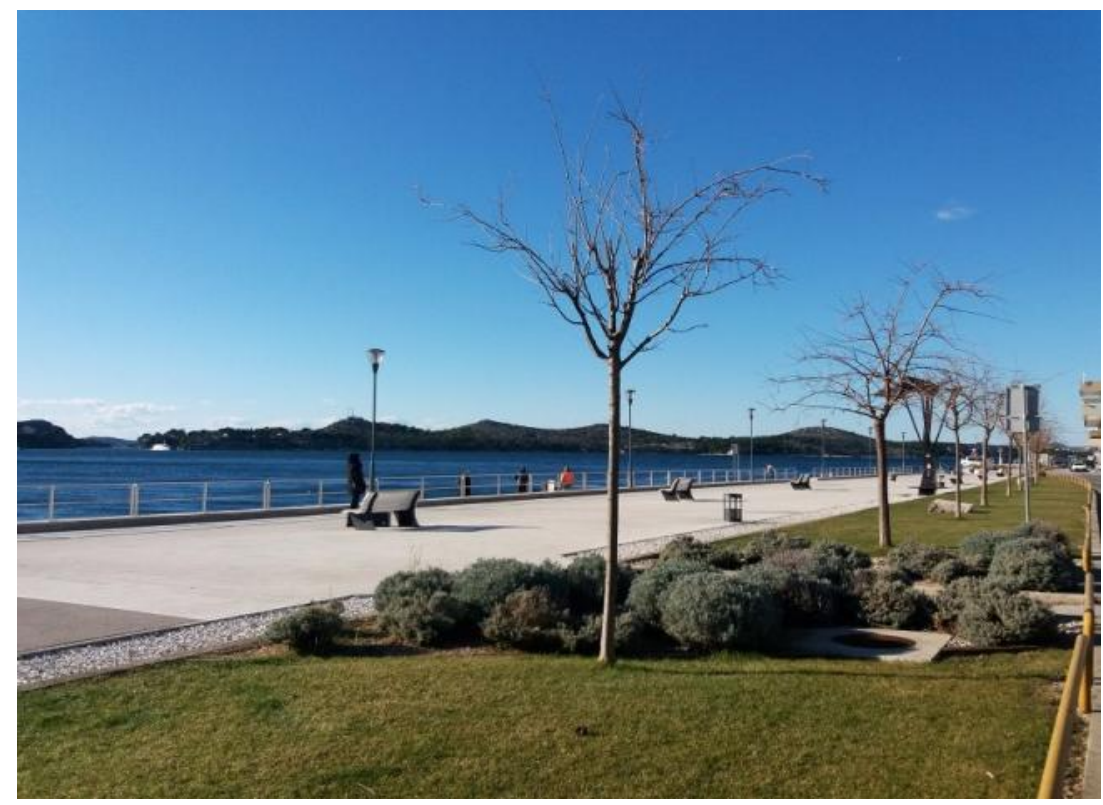

Slika 3. Pristanište Vrulje u 2018. godini (Foto: B. Dorbić).

Figure 3. Dock Vrulje in 2018 (Photo: B. Dorbić). 


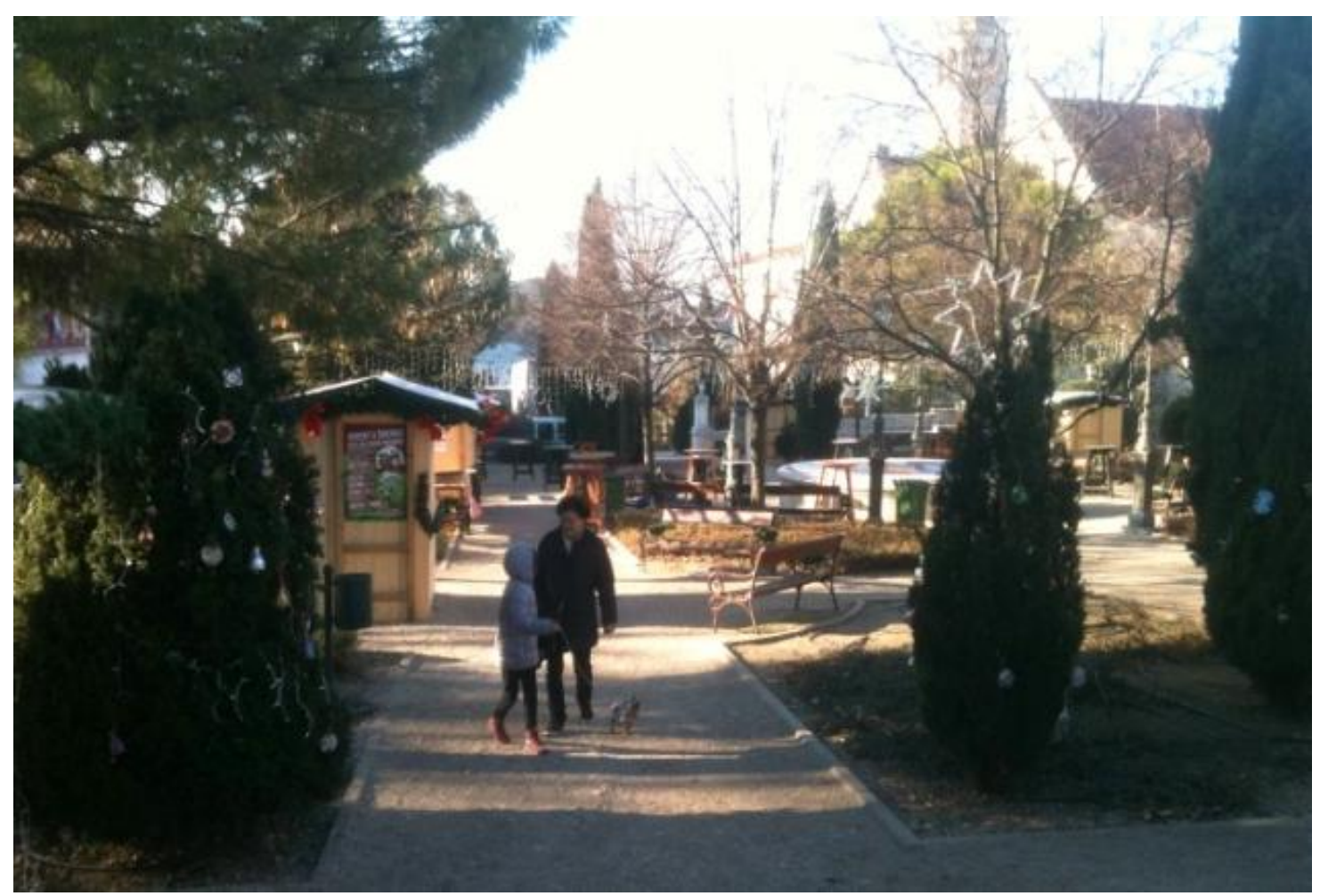

Slika 4. Advent u Perivoju Roberta Visianija (Dorbić, 2015, prema Dorbić i Temim, 2015).

Figure 4. Advent in Perivoj Robert Visiani (Dorbić, 2015, as cited in Dorbić \& Temim, 2015).

Šibenska kulturno-prirodna baština na širem teritoriju veliki je zalog objektivnom sagledavanju mogućnosti korištenja iste u simbiozi s bogatom tradicijskom kulturom i jedinstvenom cjelinom urbanog monumenta grada. Arheološki nalazi i artefakti u rasponu od gotovo 7000 godina nadopuna su modernom valoriziranju i brendiranju turističke ponude. Ona se treba smišljenom organizacijom obogaćivati u potrazi za uprizorenjem vrijednosti lokalne etnografije i bogate prošlosti kao dio cjeline životne baštine grada, a upravo je to za Šibenik i njegovo šire područje, kao i za našu Hrvatsku domovinu, jedan neiscrpni izvor i nadahnuće.

Grad je beskrajni vremeplov oriđinala, pustolova, vječitih prognanika, bune, poruge, slavljenja, glazbe i pregršt lokalizama. Upravo zbog toga su na ovom mjestu restitucije oblika uprizorenja i slike povijesnosti najpogodniji u čitavoj hrvatskoj, budući je Šibeniku na taj način omogućena slika čarobnog grada koji je lijep i kada sjećanja izmiču. Način na koji bi se promovirale ove vrijednosti moguće je oblikovati kroz pripremu materijala izvršenja različitih prezentacija, a koje bi mogle biti oživotvorene ukoliko se gradski faktori i turistička javnost bude zainteresirala. Prvi primjer nove prezentacije šibenske vrijednosti zabilježen je krajem 2017. godine kada je preko Hrvatske televizije snimljen dokumentarni film o šibenskoj luganigi čija se tradicija nastavlja već 300 godina, a u kojem je filmu autor ovog priloga kao magistar povijesti aktivno sudjelovao (Slika 5.). 


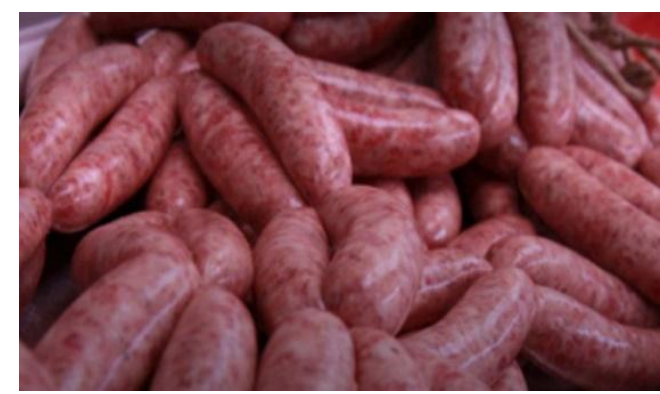

Slika 5. Šibenska kobasica luganiga ${ }^{2}$ (Anonymous, 2013).

Figure 5. Šibenik sausage luganiga ${ }^{2}$ (Anonymous, 2013).

\section{Povijesni prikaz urbanističke vrijednosti i prirodne značajke Šibenika}

Opat Ivan Đakon u drugoj polovici 10. stoljeća u svojim rukopisima, u kojima je dotakao ponajviše Veneciju i njenu prošlost, spominje za godinu 998. castrum Sebenicum što se može i pretpostaviti da se taj navod odnosi na utvrdu iznad 75 metara visoke litice, u sredini zaljeva. Očito je da je u vrijeme hrvatskih vladara Šibenik isključivo vojno-obrambeno utvrđenje, unutar kojeg su bile izgrađene nastambe za posadu kao i crkvica Sv. Mihovila. Isti će svetac kroz daljnju povijest grada postati njegov nebeski zaštitnik. Nepobitno je da je tisućugodišnji Šibenik samonikli i autohtono prvi grad kojeg su hrvati od prve utvrde do kraja 13. stoljeća podizali na obroncima južno i istočno od utvrde.

Kroz 12. i 13. stoljeće grad je dopirao do otprilike polovice obujma današnje gradske jezgre koja je od 14. stoljeća obuhvaćala prostor između sjevernih i istočnih gradskih bedema s obrambenim kulama, kao i sav prostor uz morsku obalu do današnjeg gradskog kvarta Dolac. Čak je i prvi gradski bedem od kraja 12. stoljeća prolazio ispred crkvice Svetoga Krševana (Sv. Ante za Goričane), preko tzv. Galere na prostor morske utvrde Bedem u blizini bunara Dobrić (Grubišić, 1976; Ćuzela, 2005).

Od dobivanja biskupije 1298. godine, Grad je uskoro do 1315. godine dobio i prvi Statut te se tada razvila i javno bilježnička i sudska služba. Od gusarskog odredišta Šibenik postaje civilizirano trgovište i zanatsko obrtničko središte ovog dijela dalmatinske obale. Malo je sačuvane arhitektonske baštine iz tog razdoblja srednjeg vijeka, ali se može kazati da su već i tada postojali neki sakralni spomenici kao npr. prva crkva Svetog Jakova na mjestu današnje katedrale, crkvica Sv. Kuzme i Damjana na mjestu barokne tzv. Gospe van Grada i prva crkva na mjestu samostana Sv. Frane te vjerojatno i mala crkvica Sv. Grgura u ulici Jurja Dalmatinca. Ophod gradskih bedema s 14 kula iznosio je blizu 1800 metara, a dograđivan je tijekom preuzimanja Šibenika pod mletačku vlast nakon 1412. godine. Gospodarski polet otpočinje od vremena kneza Domalda preko Bribirkih knezova Šubića, kada je Šibenik kao i veći dio hrvatske Dalmacije bio pod Ugarsko-hrvatskom upravom i

\footnotetext{
2 Šibenčani su veliki ljubitelji luganige. Kuhaju ju uglavnom u juhi kako bi kobasica pustila svoju konču. Na stolu za vrijeme blagdana luganiga se nalazi sigurno dva tjedna. Priprema se od svinjskog mesa i janjećega buta, a od mirodija se dodaju limun, mljeveni papar, cimet, korijandar, itd. (Anonymous, 2017).
} 
kraljevskom zaštitom. Gradski komunalni sustav djelomično je bio preslika iskustava prekomorskih talijanskih komuna. Tako je i bilo od početka 15. stoljeća kada u razdoblju renesansnog kulturnog pokreta počinje uspon šibenske komune u trajanju od dva stoljeća (Grubišić, 1974; Stošić, n.d.).

Gradska komuna sa svim pratećim službama javne, civilne i sudske vlasti, gradskim knezom i kapetanom, župskom organizacijom crkvenih vlasti, bratovština i kongregacija, zanatstvo, obrt i trgovina (posebno solju) bili su garant snažnog razvoja. Na prihodima porezne politike i prodajom soli Šibenik je namaknuo sredstva za izgradnju javnih cisterni, skladišta hrane (fontik), novih obrambenih bedema na istoku i zapadu grada, djelomično uređenje središnjih trgova, a zamahom građevinskih djelatnosti grad postiže velike uspjehe. To je naročito bilo izraženo kroz umjetničko oblikovanje većeg broja vjerskih objekata, palača i kuća bogatijeg i viđenijeg gradskog plemićkog sloja (Grubišić, 1976).

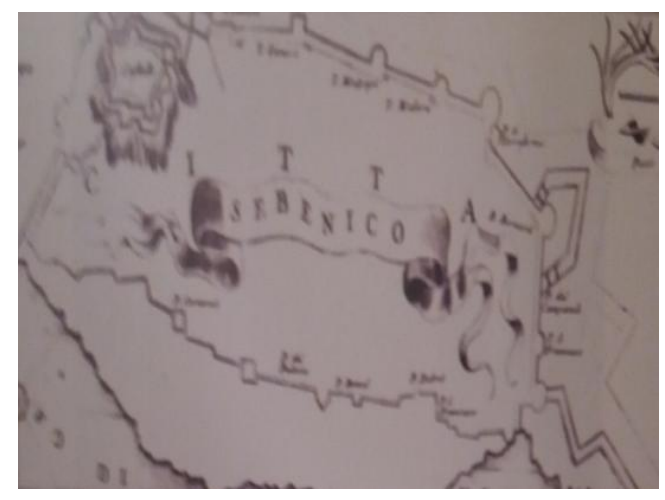

Slika 6. V. Caranelli - Tlocrt povijesne jezgre Šibenika 1688. godine (Ćuzela, 2005).

Figure 6. V. Caranelli - Ground plan of the historic core of Šibenik in 1688 (Ćuzela, 2005).

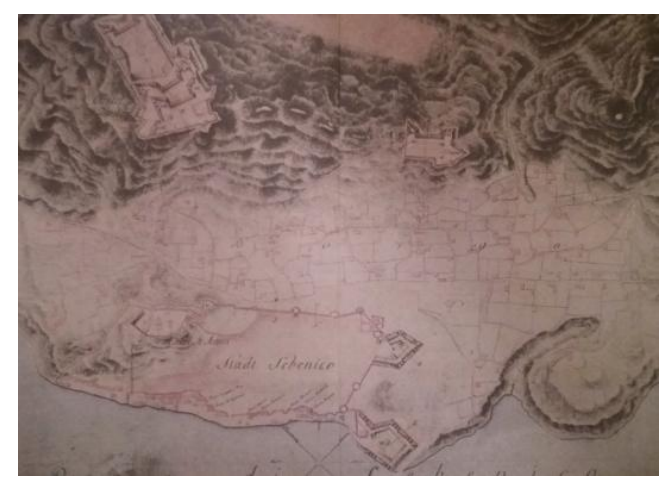

Slika 7. Plan Šibenika 1798. godine (Marković, 2009).

Figure 7. Plan of Šibenik in 1798 (Marković, 2009).

Katedrala, u izgradnji od 1431. - 1538. godine, bila je centralni poduzetno-građevinski poduhvat i podignuta je kao vrsno umjetničko djelo kasnogotičko-renesansnog razdoblja. Svakako je centralni vjerski objekt naše države i jedinstvena je po arhitektonskim recentnim novinama i skulpturi kao istaknuto djelo svjetske kulturne baštine. $\mathrm{U}$ istom razdoblju podiže se čitav niz crkvenih građevina $\mathrm{i}$ samostana, koji su dograđivani sve do kraja baroknog razdoblja (Samostan Sv. Frane, Sv. Lovre, 
Sv. Dimitrija, Sv. Dominika i Sv. Katarine). Tako je sve do kraja 18. stoljeća podignuto 26 objekata u gradu, a u tom razdoblju pa sve do novijeg vremena gotovo i 50 malih kapelica na raznim gradskim uličnim križištima. Renesansa uvodi i unutrašnji dijagonalni gradski raster u pravcu istok-zapad kroz niz od četiri glavne ulice s većim brojem pobočnih ulica pravca sjever-jug (Zenić, 2010).

Trgovački život, osim uz obalu i trgovišta Badžane (Sanitarni lazaret) u blizini Poljane u Šibeniku, odvijao se uzduž dvije ulice: današnju Kalelargu (Ruga de greci do 1850. godine) i ulicu Blgari (od Rialta do crkve Sv. Frane). Ostali prostor vezivala je današnja Zagrebačka ulica i Ulica don Krste Stošića do Samostana Sv. Lovre u dugu Ulicu Jurja Dalmatinca koja se završavala na Butu (nadsvođeni prolaz) kod crkvice Svete Katarine na početku Doca. Gradska vijećnica izgrađena do sredine 16. stoljeća upotpunila je katedralni trg, a obalni prostor kod crkve Sv. Nikole i tzv. Podstinje u Docu bili su u tom razdoblju dostatni za šibensku brodogradnju. Obalni dio kod bastiona Svete Katarine, gdje je dugo godina bilo privremeno pristanište, uređen je regulacijom 1818. godine u novo pristanište za promet razne robe u pravcima Šibenik - Venecija - Srednja Italija, a istodobno i kao stovarište robe karavanske trgovine po kojoj je Šibenik bio najznačajniji u Dalmaciji (Stošić, n.d.; Marković, 1999).

To stanje je bilo razlogom da je grad u razdoblju prvih godina 17. stoljeća brojio 6800 stanovnika, a na užem prostoru u blizini živjelo je gotovo 12000 duša, što je bila najveća urbana cjelina na Jadranu. Da je tomu tako u posljednjih 30 godina izvršena su i objavljena razna istraživanja na arhivskim izvorima u Veneciji i drugim mjestima po Italiji koja potvrđuju da je Šibenik po broju svojih građana po službi i u trgovačkim poslovima sa Mlecima bio na prvom mjestu sve do kraja 18. stoljeća i gašenja mletačkog suvereniteta 1797. godine (Anonymous a., n.d.; Čoralić, 2003).

Renesansno-barokni duh grada potvrđuje i činjenica da je Šibenik mjesto rođenja i djelovanja čitavog niza humanista, književnika, umjetnika i prirodoslovaca od J. Čulinovića, J. Dalmatinac-Orsinija, N. Fiorentinca, J. Šižgorića, A. Vrančića, F. Vrančića, I. Lukačića, M. Kolunić-Rote, D. Zavorovića, F. Difnica sve do N. Tommasea, R. Vissianija, A. Šupuka, P. Mazzollenia, V. Miagostovića i čitavog niza odličnika tijekom 20. stoljeća. Gradska jezgra svjedoči o 17 buta-prolaza i 17 većih i manjih trgova nastalih u tome razdoblju, četiri tvrđave od kojih je pomorska utvrda Sv. Nikole na ulazu u šibenski zaljev vrijedni spomenik svjetske fortifikacijske baštine iz 16 stoljeća. Živopis šibenske gradske arhitekture prezentiraju fasade palača bogatog građanstva i mnoštvo portalnih i bočnih ukrasa stupića i grbova iz raznih razdoblja života grada. Svjedočanstvo toga su kapitalna djela domaćih spisatelja o grboslovlju i šibenskim zanimljivostima u drugoj polovici 19. stoljeća (F. Galvani, A. Fenzi, A. Miagostović) (Zenić, 2003).

Talijansko iskustvo organizacije životne sredine uobličavalo se u Šibeniku kroz pokušaje organiziranja skladnog krajobraznog oblikovanja vrtova. To je karakteristično za više plemićkih obitelji među kojima su najznačajniji Divnić, Draganić, Tobolović, Pelegrini, Vrančić i drugi, a bilo je dokazom 
prihvaćanja u gradskoj sredini onog najvrjednijeg što su uz inventivnost domaćih hrvatskih graditelja primali iz prekomorskih iskustava komuna talijanskih vojvodstava kao i područja Padove i Venecije (Slika 8.). Gotičku baštinu dijelom je poremetila manija austrijske uprave o izmijenjenim oblicima prozora i balkona kod obnove gradskih fasada od početka 19. stoljeća, što je promijenilo dio vizura gradskih ulica. Tomu treba dodati i odluku pokrajinskih vlasti u Zadru kada se iz sanitarnozdravstvenih razloga godine 1889. - 1890. godine ruši veći dio gradskih bedema od kojega je kamenog materijala Pomorska uprava Dalmacije započela izgradnju novo operativno trgovačke obale i pristaništa (Anonymous b., n.d.).

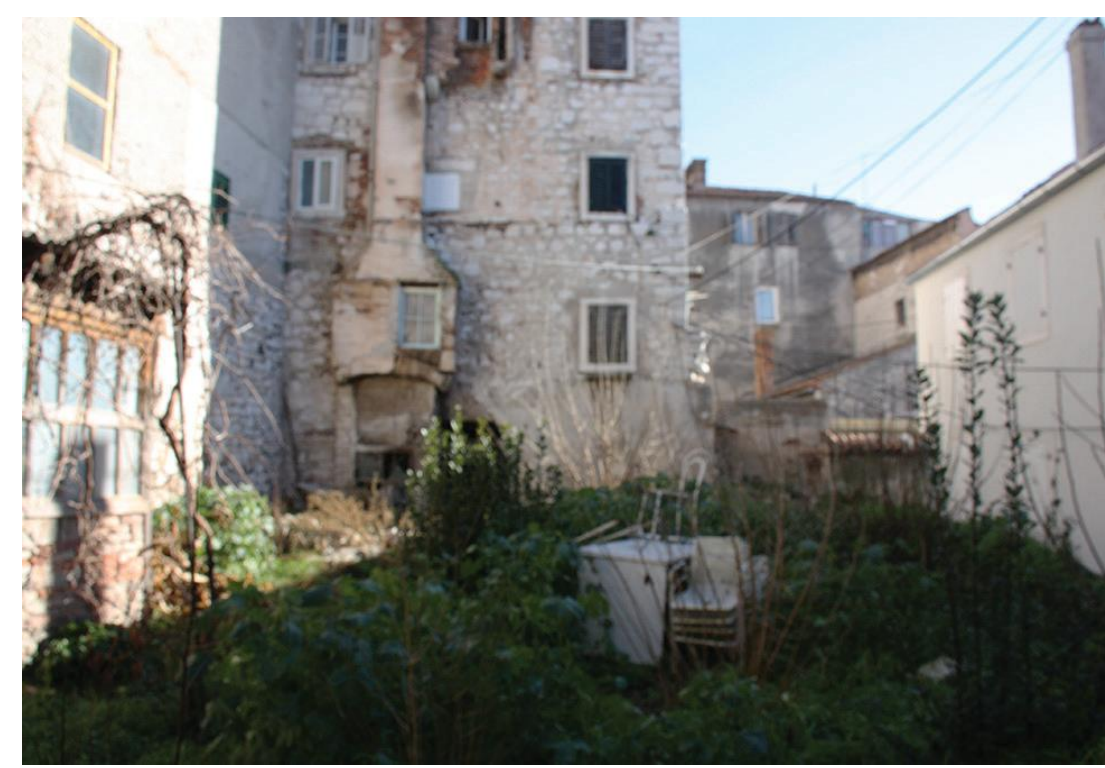

Slika 8. Vrt obitelji Divnić na Gorici (Dorbić 2015, prema Dorbić i Temim 2016) ${ }^{3}$.

Figure 8. Garden of the Divnić family in Gorica (Dorbić 2015, as cited in Dorbić \& Temim, 2016).

Struktura gradske jezgre u svojoj specifičnosti koji je prostor nametao može se sublimirati u ocjeni autora teksta o Šibeniku kao gradu Optimizma neposredne budućnosti iz 1975. godine objavljenom u Informativnom Privrednom pregledu gdje se bilježi: Grad, Gorica i Dolac su tri gradska predjela različito socijalno-gospodarske, ali vrlo homogene strukture s izuzecima pojedinih javnih i sakralnih građevina ili patricijskih palača gdje dolac svojim smještajem među dva gradska zida ima izraziti karakter predgrađa (Anonymous, 1975) (Slike 9. i 10.).

\footnotetext{
${ }^{3}$ Dorbić (2015, prema Dorbić i Temim 2016): Šibenska plemićka obitelj Divnić je pripadala istaknutom i bogatijem sloju gradskog šibenskog plemstva od sredine 15. stoljeća. Isticali su se u obavljanju raznih svjetovnih-javnih, kulturnih i crkvenih funkcija, a pojedini članovi Šibenika i u obrani grada za vrijeme Turskih vojnih pohoda u Dalmaciji. Vrt obitelji Divnić čiji se ostaci i danas nalaze u šibenskom predjelu Gorica (Ex. Galera) iznad tzv. stuba Dragojevića je oblikovan u srednjevjekovnom stilu s centralnom osi i bočnim alejama odvojenim dvostrukom kolonadom kamenih stupića krajem 16. stoljeća. Kao takav služio je kao dnevno odmaralište gradskog plemićkog sloja. U vrtu su krajem 2015. godine popisane sljedeće biljne vrste: smokva (Ficus carica L.), dud (Morus sp.), badem (Prunus dulcis (Mill.), šipak (Punica granatum L.), vinova loza (Vitis vinifera L.), bršljan (Hedera helix L.), kana (Canna sp.), perunika (Iris germanica L.), velika zimzelen (Vinka major L.). Sadašnje stanje ukrasnog bilja ukazuje na neujednačenost u općoj kompoziciji biljnog materijala, budući su se posljednjih desetljeća vrt nestručno održavao.
} 


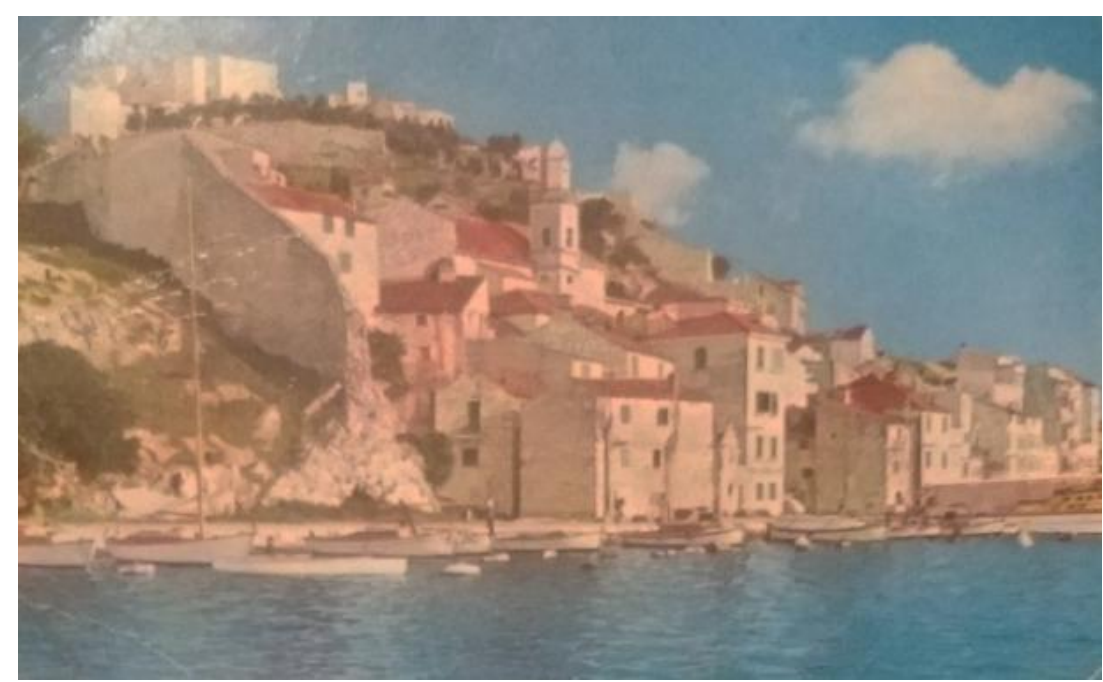

Slika 9. Dolac 1969. godine (Blažević, n.d.).

Figure 9. Dolac 1969 (Blažević, n.d.).

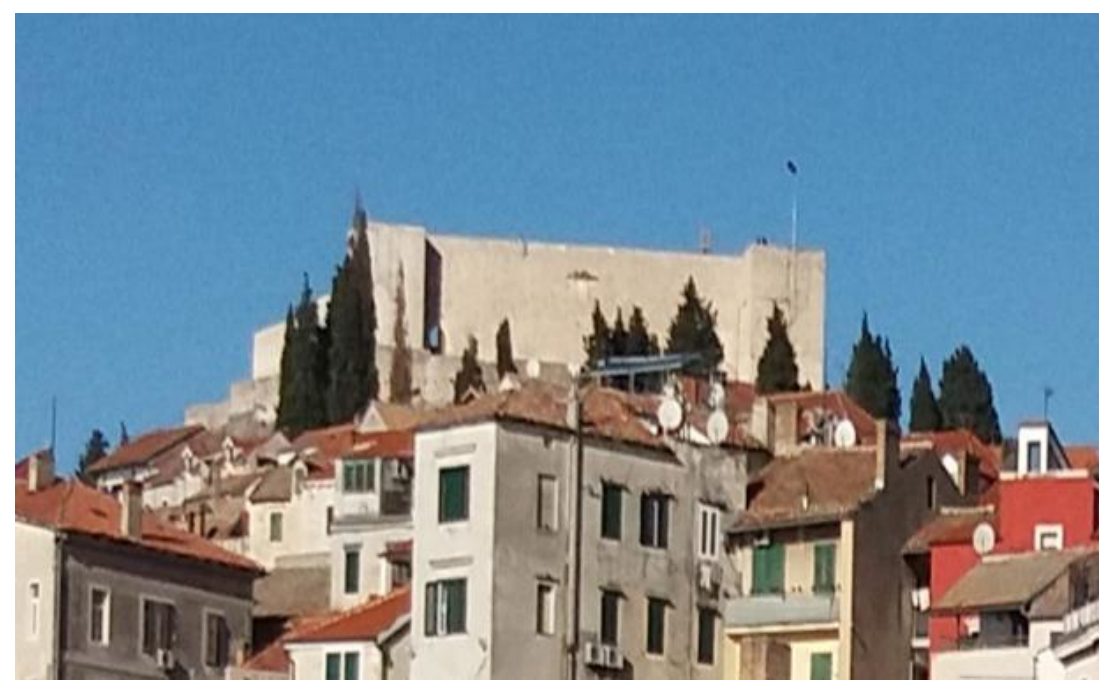

Slika 10. Tvrđava Sv. Mihovila 2018. godine (Foto: B. Dorbić).

Figure 10. Fortress St. Michael in 2018 (Photo: B. Dorbić).

Ovu sliku Šibenika daje i izuzetni gradski krajobraz s ukrasnim biljem kao rezultat ukupne sastavnice hedonizma građanskog života (Dorbić i Temim, 2015), a koji svoju odrednicu definira i na susjednom otočju kao npr. Zlarinu, Prviću, Krapnju i Murteru. Prirodna baština okoliša, razvedenost šibenskog zaljeva, areal Gornjeg i Donjeg polja i blistavi Slapovi i cjelina rijeke Krke dopunjava baštinski značaj i zalog su korištenja tih vrijednosti u moderni doživljaj globalne turističke perspektive (Slike 11. i 12.). 


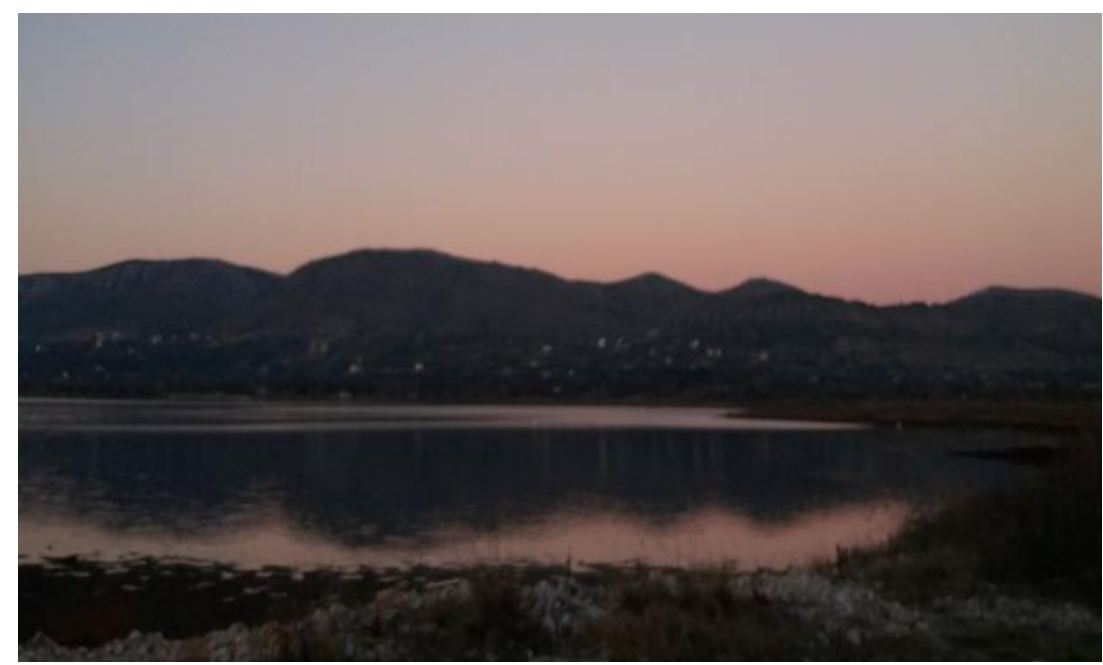

Slika 11. Pogled na Morinjsko jezero i Donje Polje 2018. godine (Foto: B. Dorbić).

Figure 11. View in Morinjsko jezero and Donje Polje in 2018 (Photo: B. Dorbić).

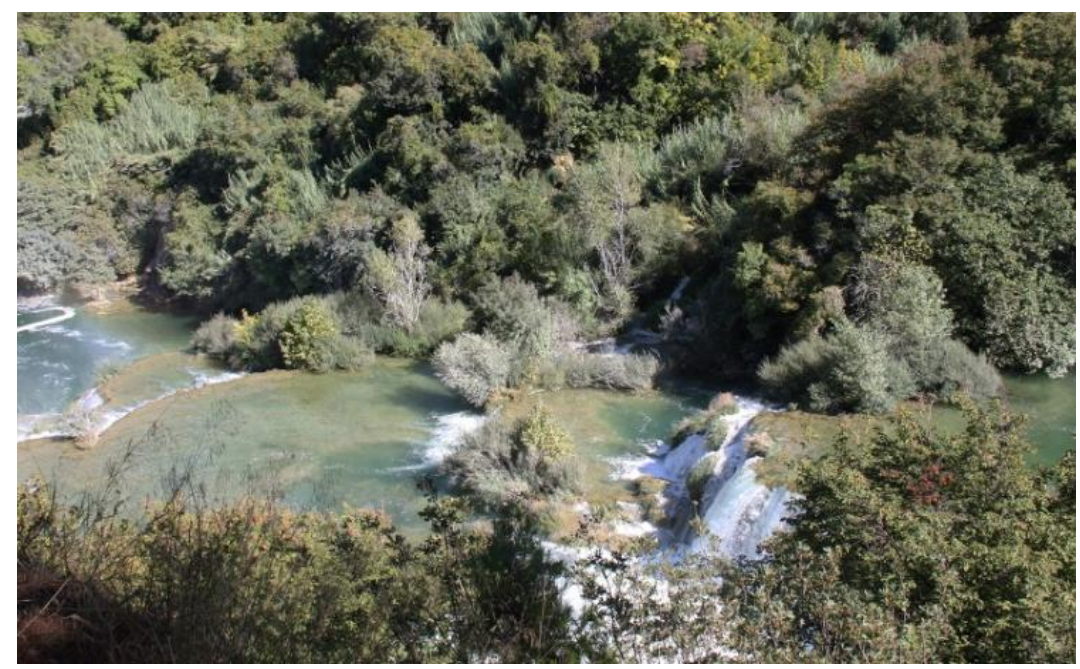

Slika 12. Slapovi Krke 2014. godine (Foto: B. Dorbić).

Figure 12. Krka waterfalls in 2014 (Photo: B. Dorbić).

Ti su počeci u Šibeniku otpočeli 1841. godine kada je u blizini Crkve Svetog Ivana podignut prvi mini hotel Albergo Pellegrino. To nije bio hospicij ili svratište, već prvo malo mjesto za odmor koje je u svom opusu u jednom izvješću u knjizi Aus Dalmatien objavila poznata njemačka putopisna spisateljica Ida von Duringsfeld 1857. godine.

\section{Zaključak}

Temeljem iznesenih činjenica u radu može se utvrditi da je sačuvana kulturno-povijesna baština Šibenika koju su stvarali mnogi poznati i nepoznati građani iz različitih socijalnih staleža uputila novoj generaciji pučanstva ovog grada snažnu sliku vrijednosti koju valja sačuvati i brendirati kao kulturnu ostavštinu na korist turističko-gospodarske valorizacije kao segmenta novog oblika privređivanja 
budućnosti grada i lokalne zajednice. Bogata i nepresušna baština jednostavno nas upućuje i traži da se u suvremenosti izvuče iz naslaga povijesnosti kao moderna brendirana slika životne budućnosti.

\section{Literatura}

Anonymous a. (n.d.). HR-DAŠI-1 Općina Šibenik (Comune civitatis et districtus Sibenici) 1690. -1797 .

Anonymous b. (n.d.). HR-DAŠI-5 Općinsko upraviteljstvo/kotarsko poglavarstvo Šibenik (Amministrazione comunate, Podesta comunale) 1813. - 1918.

Anonymous (1975). Šibenik grad optimizma neposredne budućnosti. Informativni privredni pregled Beograd.

Anonymous (2013). Luganige radimo po receptu starog meštra Bege, s požutjelog papira. Posjećeno 20. 12. 2018. na mrežnoj stranici Šibenskog portala: http://sibenskiportal.rtl.hr/2013/12/26/luganige -radimo-po-receptu-starog-mestra-bege-s-pozutjelog-papira/.

Blažević, M. (n.d.). Privatna zbirka razglednica. Šibenik.

Ćuzela, J. (2005). Šibenski fortifikacijski sustav. Šibenik: Gradska knjižnica "Juraj Šižgorić" Šibenik.

Čoralić, L. (2003). Šibenčani u Mlecima. Šibenik: Gradska knjižnica "Juraj Šižgorić" Šibenik.

Dorbić, B., Temim, E. (2015). Povijesni pregled razvoja vrtlarstva i krajobraznog uređenja Šibenika i okolice u razdoblju 1945. - 1985. godine. Annales - Anali za Istrske in Mediteranske Studije - Series Historia et Sociologia, 25(3), 637 - 650.

Dorbić, B., Temim, E. (2016). Povijesni pregled razvoja vrtlarstva i krajobraznog uređenja Šibenika i okolice u razdoblju 1880. - 1945. godine. Annales - Anali za Istrske in Mediteranske Studije - Series Historia et Sociologia, 26(2), 227-246.

Dorbić, B., Temim, E. (2018). Valorizacija dendro elemenata u parkovima i pejsažnim površinama na području Šibensko-kninske županije. Annales - Anali za Istrske in Mediteranske studije - Series Historia et Sociologia, 28(1), 167-192.

Grubišić, S. (1974). Šibenik kroz stoljeća. Šibenik: Muzej grada Šibenika.

Grubišić, S. ured. (1976). Šibenik: spomen o 900. obljetnici. Šibenik: Muzej grada Šibenika.

Marković, J. (2009). Šibenik u doba modernizacije. Zagreb i Šibenik: Institut za povijest umjetnosti, Gradska knjižnica "Juraj Šižgorić" Šibenik.

Maroević, I. (1986). Sadašnjost baštine. Zagreb: Društvo povjesničara SR Hrvatske. 
M. Blažević / Ogled o urbanim i prirodnim vrijednosnicama Šibenika u kontekstu turističke perspektive / Glasilo Future (2018) 1 (5-6) 28-40

Pančić Kombol, T. (2006). Kulturno nasljeđe i turizam. Radovi Zavoda za znanstveni rad Varaždin, (16-17), 211-226.

Poljičak, I. (2014). Utjecaj suvremenog kulturnog turizma na promjene načina života u starim gradskim jezgrama na hrvatskoj obali. Zbornik radova Veleučilišta u Šibeniku, (1-2), 83-89.

Stošić, K. (n.d.). Zbirka rukopisa i bilješki iz šibenske prošlosti. Šibenik: Muzej grada Šibenika.

Zenić, M. (2010). Stari Šibenik kalama, skalama i butama. Zagreb: AGM.

Primljeno: 19. prosinca 2018. godine

Prihvaćeno: 31. prosinca 2018. godine
Received: December 19, 2018

Accepted: December 31, 2018 